\title{
Characterization of a U.S. Isolate of Beet black scorch virus
}

\author{
John J. Weiland, David Van Winkle, Michael C. Edwards, Rebecca L. Larson, \\ Weilin L. Shelver, Thomas P. Freeman, and Hsing-Yeh Liu
}

First and second authors: Sugarbeet and Potato Research Unit, third author: Cereal Crops Research Unit, and fifth author: Animal Metabolism Research Unit, U.S. Department of Agriculture-Agricultural Research Service (USDA-ARS), Fargo, ND 58105; fourth author: Crops Research Laboratory, USDA-ARS, Fort Collins, CO 80526; sixth author: Department of Plant Pathology, North Dakota State University, Fargo 58105; and seventh author: Sugarbeet Production Laboratory, USDA-ARS, Salinas, CA 93905.

Current address of first author: Cereal Crops Research Unit, USDA-ARS, Fargo, ND 58105.

Accepted for publication 15 May 2007.

\begin{abstract}
Weiland, J. J., Van Winkle, D., Edwards, M. C., Larson, R. L., Shelver, W. L., Freeman, T. P., and Liu, H.-Y. 2007. Characterization of a U.S. isolate of Beet black scorch virus. Phytopathology 97:1245-1254.

The first reported U.S. isolate of Beet black scorch necrovirus (BBSV) was obtained and characterized. Host range of the virus for localized and occasionally systemic infection included the Chenopodiaceae and Tetragonia expansa; Nicotiana benthamiana supported symptomless systemic infection by the virus. The complete nucleotide sequence of the genomic RNA of the virus, designated BBSV-Co, exhibits $93 \%$ similarity to the genome of the 'Ningxia' isolate of BBSV from China. Amino acid se-

quence similarity in predicted genes ranged from $95 \%$ in the $p 4$ gene to $97 \%$ in the $p 82$ and coat protein genes. A potential additional gene exists within the U.S. isolate of BBSV that is absent from Chinese isolates of BBSV due to nucleotide differences between these isolates within the coat protein gene. Coat protein analysis by isoelectric focusing and by mass spectroscopy indicated the presence of phosphorylated residues. Using primer extension analysis of the $5^{\prime}$ end of the genome and sitedirected mutants of genomic clones of BBSV-Co from which infectious RNA was produced, the native $5^{\prime}$ end of the BBSV-Co genome was determined to be 5'-GAAACCTAACC...3', lacking the two terminal adenosine nucleotides in the published sequences of BBSV from China.
\end{abstract}

Beet black scorch virus (BBSV) was first reported in Inner Mongolia of China, where it was obtained from diseased sugar beet plants. Symptoms attributed to infection by the virus included a black scorching of leaf tips and severe stunting of affected plants $(6,9)$. The virus appears to exacerbate symptoms produced by Beet necrotic yellow vein virus (BNYVV), which causes the well-known 'Rhizomania' disease of sugar beet (10). Recently, BBSV was reported for the first time in the United States, where it was found associated with sugar beet exhibiting Rhizomania symptoms, even in cases where BNYVV was not detectable (32).

BBSV is a plant necrovirus within the family Tombusviridae $(25,33)$. The virus was shown to be transmitted in the soil to host roots by the Chytrid vector Olpidium brassicae under laboratory conditions, although it was not indicated whether black scorch symptoms resulted from infection in this study (18). BBSV readily infects the leaves of members of the family Chenopodiaceae, inducing necrotic local lesions with chlorotic halos 3 days after the inoculation of Chenopodium quinoa and C. amaranticolor; systemic symptoms induced by BBSV in $C$. quinoa commonly were observed. Complete sequence of the positivestrand 3,644-nucleotide (nt) genome for two isolates of BBSV from China, 'Xinjiang' (BBSV-X) and 'Ningxia' (BBSV-N), indicates the presence of seven open reading frames (ORFs) organized similarly to those in other necroviruses $(7,34)$. The isolates

Corresponding author: J. J. Weiland; E-mail address: john.weiland@ars.usda.gov

* The $e$-Xtra logo stands for "electronic extra" and indicates that the online contains version contains a table not included in the print edition. The online table shows the host range of Beet black scorch virus by mechanical inoculations.

doi:10.1094/PHYTO-97-10-1245

This article is in the public domain and not copyrightable. It may be freely reprinted with customary crediting of the source. The American Phytopathological Society, 2007.
BBSV-N and BBSV-X differ at 20 nt positions and are $99 \%$ similar. Cloned DNA from which infectious RNA can be transcribed recently was used to map the $5^{\prime}$ ends of the two major subgenomic RNAs and to determine the role of the central and $3^{\prime}$ end ORFs in virus replication and movement (34).

Sugar beet production in the United States has been impacted highly in recent years by Rhizomania, a disease potentially aggravated by the presence in U.S. soils of the related beet soilborne mosaic virus (BSBMV) (24). Of increasing concern is the occurrence of sugar beet plants exhibiting symptoms of Rhizomania that nevertheless test negative for the presence of BNYVV or BSBMV by enzyme-linked immunosorbent assay (ELISA). A bioassay for detecting novel viruses in several sugar beet samples exhibiting this phenomenon revealed the presence of BBSV (designated BBSV-Co) in a production field in Colorado in 2005 (32). It is noteworthy that the samples exhibited no black scorch leaf symptoms; indeed, the ability and degree to which BBSV impacts sugar beet remains poorly characterized.

In this study, the complete nucleotide sequence of an infectious cDNA clone of the Colorado isolate of BBSV (pBBSV-Co4) was obtained. The genome of BBSV-Co is 3,642 bases in length. We show that discrepancies between the experimental and calculated isoelectric point of the BBSV coat protein $(\mathrm{CP})$ can be accounted for, in part, by the presence of phosphorylated residues. Although numerous nucleotide differences exist between the U.S. and Chinese isolates of BBSV, it is proposed that BBSV lacks the two $5^{\prime}$ terminal adenosine nucleotides present in the previously published sequences of BBSV-N and BBSV-X.

\section{MATERIALS AND METHODS}

Virus acquisition, host range analysis, and electron microscopy. Plants of sugar beet (Beta vulgaris L.) hybrid ACH9369 and $C$. quinoa cv. Tango were grown in a greenhouse supple- 
mented with artificial lighting to produce a 16-h day length. Lateral roots and root hairs from washed sugar beet roots exhibiting Rhizomania-like symptoms were ground in $0.1 \mathrm{M}$ sodium phosphate buffer, $\mathrm{pH}$ 7.0. The extract was used to inoculate C. quinoa mechanically with a gloved finger using Carborundum (400 grit; VWR Scientific Products, West Chester, PA) as a mild abrasive. Transfer of a single chlorotic lesion generated the isolate described herein.

Tests of host range were performed by transfer of virus from infected $C$. quinoa to the leaves of healthy test plants using mechanical inoculation as above. Inoculated plants were maintained under natural lighting in a greenhouse with a temperature range of 26 to $32^{\circ} \mathrm{C}$. Plants were assessed visually for symptoms at 4 to 12 days postinoculation (dpi). Presence of virus in test plants was confirmed by back inoculation to $C$. quinoa.

Infected $C$. quinoa specimens were prepared for electron microscopy by fixing for a minimum of $2 \mathrm{~h}$ at $4^{\circ} \mathrm{C}$ in $2.5 \%$ glutaraldehyde in $0.1 \mathrm{M}$ sodium phosphate buffer, $\mathrm{pH}$ 7.4. Samples were rinsed in sodium phosphate buffer, then transferred to phosphatebuffered $2 \%$ osmium tetroxide and incubated at room temperature for $2 \mathrm{~h}$. Samples were dehydrated in a graded series of acetone, ending at a final acetone concentration of $100 \%$. Uranyl acetate was applied as a stain in the $70 \%$ acetone stage. Following dehydration, samples were embedded in Epon-Araldite-DDSA and sectioned at a $60-\mathrm{nm}$ thickness. Sections were stained with lead citrate for 2.5 min before observation and photography on a JEOL JEM-11CX II electron microscope. Purified virus samples were placed on carbon-coated formvar grids and stained with $1 \%$ buffered phosphotungstic acid prior to observation and photography.

Virus purification and RNA blotting. Virus-infected leaves of C. quinoa were harvested at $4 \mathrm{dpi}$ for the analysis of virus products and virus purification. Infected leaves were ground in a cold solution ( $3 \mathrm{ml} \mathrm{g}^{-1}$ fresh weight of tissue) buffered with $0.1 \mathrm{M}$ sodium acetate, $\mathrm{pH} 5.2 ; 0.1 \mathrm{M}$ sodium citrate, $\mathrm{pH}$ 6.0; or sodium phosphate, $\mathrm{pH} 7.0$; each containing $1 \mathrm{mM} \beta$-mercaptoethanol and one-half volume of chloroform. The suspension was clarified by filtration through Miracloth (Calbiochem, La Jolla, CA USA) and centrifugation at $4,000 \times g$ for $15 \mathrm{~min}$ at $4{ }^{\circ} \mathrm{C}$. The supernatant was adjusted to $10 \%$ polyethylene glycol (PEG) 8000 and placed on ice for $30 \mathrm{~min}$. Following a centrifugation at 12,000 $\times g$ for $15 \mathrm{~min}$ at $4{ }^{\circ} \mathrm{C}$, the pellet was emulsified in additional chloroform along with $1 / 10$ concentration of the original buffer used and omitting the $\beta$-mercaptoethanol. This was centrifuged at 5,000 $\times$ $g$ for $10 \mathrm{~min}$ to separate the aqueous and organic phases. The aqueous phase was adjusted to $10 \%$ PEG 8000 and $0.1 \mathrm{M} \mathrm{NaCl}$ and incubated on ice for $60 \mathrm{~min}$. The mixture was centrifuged at $12,000 \times g$ for $20 \mathrm{~min}$ and the supernatant removed. Pelleted virus was resuspended in $10 \mathrm{mM}$ TRIS- $\mathrm{HCl}, \mathrm{pH} \mathrm{7.2,} \mathrm{and} \mathrm{used} \mathrm{for}$ protein and nucleic acid analysis by gel electrophoresis.

Virus for antisera production was further purified by high-speed ultracentrifugation at $120,000 \times g$ for $1.75 \mathrm{~h}$. After resuspension of pellets in $10 \mathrm{mM}$ TRIS-HCl (pH 7.2), the preparations were centrifuged at $10,000 \times g$ for $10 \mathrm{~min}$. The supernatants then were centrifuged through a $20 \%$ sucrose pad at $150,000 \times g$ for $1.5 \mathrm{~h}$. Final pellets were resuspended again in $10 \mathrm{mM}$ Tris- $\mathrm{HCl}, \mathrm{pH} 7.2$. An approximate extinction coefficient $\left(\mathrm{E} 260^{0.1 \%}\right)$ of 5.0 was used for estimating virus yield (13).

Total nucleic acids for northern blot analysis and infectivity assays were extracted from infected plants and purified virus as described by Weiland and Edwards (31). Nucleic acid samples were glyoxalated, separated by electrophoresis, and stained with ethidium bromide according to the procedure outlined by Sambrook and Russell (26). Northern blots of separated products followed the protocol provided in the digoxigenin (DIG) DNALabeling and Detection Kit (Roche Applied Science, Indianapolis, IN) using polymerase chain reaction (PCR)-based incorporation of DIG-dUTP for probe synthesis (utilizing primers BBSV3UTRfwd; 5'ATTAGATCCCACATCCTGGTGTGGTTAATC3' and BBSV3'rev) (Fig. 1) and chemiluminescence for the detection of probe-target hybrids.

CP purification and analysis. The viral CP size was determined by comparison to molecular weight standards (Bio-Rad, Hercules, CA) using sodium dodecyl sulfate polyacrylamide gel electrophoresis (SDS-PAGE) with a $12 \%$ polyacrylamide resolving gel. The protein band of interest was excised from the gel and digested using a ProteoProfile trypsin digest kit (Sigma-Aldrich, St. Louis). Tryptic peptides were purified and concentrated on C18 ZipTip pipette tips (Millipore, Brillerica, MA) according to the manufacturer's recommendations. Eluted peptides were diluted 1:1 in matrix ( $\alpha$-cyano-4-hydroxy-cinnamic acid, $10 \mathrm{mg} \mathrm{ml}^{-1}$; Bruker Daltonics, Billerica, MA) and spotted in duplicate onto stainless steel matrix-assisted laser desorption ionization (MALDI) plates (Applied Biosystems, Foster City, CA).

Peptide mass determination of the purified $\mathrm{CP}$ was determined through MALDI time-of-flight mass spectrometry (TOF MS) using a high-resolution Bruker Ultraflex tandem MALDI-TOF

\begin{tabular}{|c|c|c|}
\hline \multicolumn{3}{|c|}{ tagtatacataccaagtatacgataccggtgcaag } \\
\hline OMMV & \multicolumn{2}{|l|}{ agtatacataccaagtatacggaataggtg } \\
\hline TNV-A & \multicolumn{2}{|c|}{ agtattcataccaagaataccggataggtgcgaagcctta } \\
\hline TNV-A & \multicolumn{2}{|c|}{ ccaagaataccaaataggtg } \\
\hline LWSV & \multicolumn{2}{|c|}{ gatacctaaccagtgtctcgttgatcagtg } \\
\hline TNV-D & \multicolumn{2}{|c|}{ gatacctaaccagtgtctc } \\
\hline \multicolumn{3}{|c|}{ gaaagctacgtggtcatggt } \\
\hline \multicolumn{3}{|c|}{ BBSV-N genome $5^{\prime}$ end } \\
\hline BBT75fwd & TAATACGACTCACTATAG ${ }^{\star}$ AAGAAACCTAACCAGTTTCTCG & (pBBT7GAAG) \\
\hline BBT75fwd2 & TAATACGACTCACTATAG*AGAAACCTAACCAGTTTCTCG & (pBBT7GAG) \\
\hline BBT75fwd3 & TAATACGACTCACTATAG*GAAACСТAACCAGTTTCTCG & (pBBT7GG) \\
\hline BBT75fwd4 & TAATACGACTCACTATAG ${ }^{\star}$ AAACСTAACCAGTTTCTCG & (pBBT7G; pBBSV-Co4) \\
\hline BBT75fwd5 & TAATACGACTCACTATAG ${ }^{* A A C C T A A C C A G T T T C T C G ~}$ & (pBBT7A) \\
\hline
\end{tabular}

\section{BBSV3rev GGGCACCTGGAAGACCAGGTATATAAG}

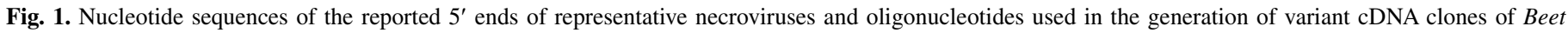

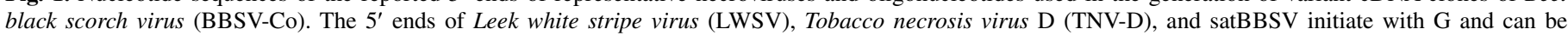

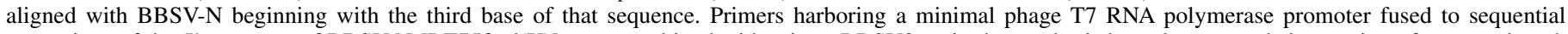

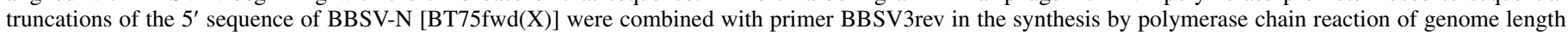

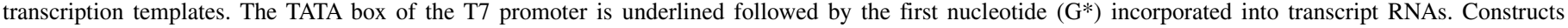

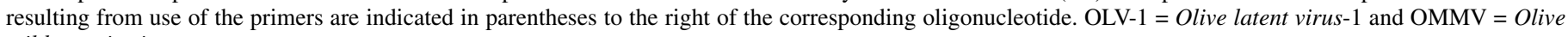
mild mosaic virus. 
MS in the positive reflectron mode with a $200 \mathrm{~Hz} \mathrm{Nd-YAG}$ 355-nm laser. Displayed spectra were obtained by averaging 1,000 acquired spectra in the MS mode or 2,500 in the MS/MS mode. Collision-induced dissociation (CID), with air as the collision gas at approximately $1 \times 10^{-6}$ Torr and a $1-\mathrm{keV}$ acceleration voltage, was used for obtaining the MS/MS spectra of selected peptides. Conversion of time-of-flight to mass (Da) for the monoisotopic ions $[\mathrm{M}+\mathrm{H}]^{+}$was based on calibration of the instrument with a peptide standard calibration kit (Applied Biosystems). The MS/MS TOF calibration was obtained from the CID-produced fragments of $\mathrm{Glu}^{1}$-fibrinopetide B. Peptide mass fingerprints and MS/MS of selected peptides were combined and queried against the primary sequence database using the Mascot (Matrix Science, Inc., Boston) search engine through GPS Explorer Software (Applied Biosystems) with $50 \mathrm{ppm}$ for $\mathrm{MS}$ and $0.1 \mathrm{Da}$ for MS/MS as error tolerance. Phosphorylation of the intact CP was detected by MALDI MS. Prediction of phosphorylation sites was completed using NetPhos 2.0 (4) (Center for Biological Sequence Analysis, Technical University of Denmark, Lyngby, Denmark).

The isoelectric point $(\mathrm{pI})$ of the $\mathrm{CP}$ was determined by isoelectric focusing (IEF). Immobile IEF strips (pH 3 to $10,110 \mathrm{~mm}$; GE Healthcare, Piscataway, NJ) were rehydrated overnight in $8 \mathrm{M}$ urea, 2\% (wt/vol) CHAPS, $0.002 \%$ (wt/vol) bromophenol blue, and $2 \%(\mathrm{vol} / \mathrm{vol})$ ampholytes ( $\mathrm{pH} 3$ to 10 ; Bio-Rad) containing $50 \mu \mathrm{g}$ of total viral protein. IEF was run under the following conditions: $1 \mathrm{~h}$ at $300 \mathrm{~V}(1 \mathrm{~mA}, 5 \mathrm{~W})$ followed by $3.75 \mathrm{~h}$ at 3,000 $\mathrm{V}$. The IEF strip was silver stained and the $\mathrm{pI}$ of the $\mathrm{CP}$ was inferred through comparison to a parallel run of IEF standards (Sigma-Aldrich). Computer-based prediction of the CP pI was based on the amino acid sequence contained in the GenBank database for BBSV-N following the protocol of Bjellqvist et al. (3).

Rabbit antisera production. Two New Zealand white rabbits were immunized with purified BBSV $(1 \mathrm{mg} / \mathrm{rabbit}$ per immunization cycle) emulsified with Imject Alum (Pierce Biotechnology, Inc., Rockford, IL). The emulsion was injected into each rabbit (four subcutaneous sites on the back, $0.1 \mathrm{ml} \mathrm{site}^{-1}$, and four intra-

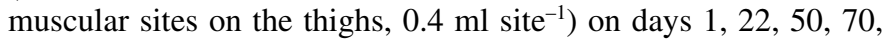
and 91 . The sera were harvested 7 days after the day-91 immunization and the aliquot stored at $-20^{\circ} \mathrm{C}$ until used. Serum immunoglobulin $\mathrm{G}(\mathrm{IgG})$ and $\mathrm{IgG}$-alkaline phosphatase (AP) conjugate were prepared as previously described (8).

Standard ELISA using AP-conjugated IgG was performed as described by Clark and Adams (8). Purified IgG used at $0.5 \mu \mathrm{g}$ $\mathrm{ml}^{-1}$ for plate coating and $1 \mu \mathrm{g} \mathrm{ml}^{-1}$ as an AP conjugate detected $30 \mathrm{pg}$ of purified virus within $30 \mathrm{~min}$ of incubation with $p$-nitrophenyl phosphate. Subsequent western blot detection of proteins fractionated by $14 \%$ SDS-PAGE was performed as described by Weiland and Edwards (31). Primary antiserum was diluted 1:5,000 for detection of immobilized antigen on nitrocellulose membranes using secondary antibody and chemiluminescent detection reagents supplied within the ECL kit (GE Healthcare, Inc.).

Viral RNA characterization, cloning, and transcript infectivity. Extraction of total nucleic acids from healthy and infected C. quinoa leaves and from partially purified virus was performed as previously described $(30,31)$. Infectivity of the RNA extracted from virus preparations and of transcript RNA was tested by suspending 2 to $5 \mu \mathrm{g}$ of RNA in GKP buffer $(50 \mathrm{mM}$ glycine, $30 \mathrm{mM} \mathrm{K} \mathrm{HPO}_{4}, 1 \%$ bentonite, and $1 \%$ celite, $\mathrm{pH} 9.2$ ) and mechanically inoculating leaves of $C$. quinoa and sugar beet (31). The Smart rapid amplification of cDNA ends (RACE) kit (Clontech Inc., Mountain View, CA), which includes a high-fidelity, thermostable polymerase, was used to clone cDNA fragments generated from the virion RNA. Sequencing was performed by Northwoods DNA, Inc. (Solway, MN) and Iowa State University (Ames).

Oligonucleotide primers were designed for the amplification of the complete BBSV genome by reverse-transcription (RT)-PCR.
The bacteriophage T7 RNA polymerase promoter core sequence was fused to the $5^{\prime}$ terminal 22 bases of the BBSV-N sequence to produce primer BBT75fwd (Fig. 1). This was used in conjunction with primer BBSV3rev to produce a genome-length amplicon using the Clontech Smart PCR cDNA synthesis kit (Clontech Inc.). The amplicon was cloned into the pCR 2.1 vector using the TOPO-TA cloning method (Invitrogen Inc., Carlsbad, CA).

$E c o$ R1 digestion of clones liberated the cloned insert from the plasmid vector, providing a template from which transcription would initiate one $\mathrm{G}$ nucleotide before the viral sequence (Fig. 1). Based on the predicted structure of the excised insert, the $3^{\prime}$ end of the transcripts would harbor the sequence $5^{\prime}$...CCCAGGGCGAAUU-3', where the italicized letters represent the last 3 bases of the BBSV genome. Transcription reactions with T7 RNA polymerase for generating uncapped RNA as previously described (31) were used to produce genome-length RNA for inoculation to plant leaves. The clone with demonstrated infectivity was designated pBBSV-GAAG.

Variant genomes differing in $5^{\prime}$ end sequence were produced using pBBSV-GAAG as a template for PCR. Primer BBSV3rev was used in combination with $5^{\prime}$ end primers designed to produce amplicons with a decreasing number of $5^{\prime}$ bases on the genomic sequence (Fig. 1). Amplicons were cloned into pCR2.1 and the 5' ends sequenced to confirm presence of the mutations: Clones were designated pBBT7GAAG, pBBT7GAG, pBBT7GG, pBBT7G, and pBBT7A in the order of decreasing number of terminal nucleotides. Cloned inserts were released from the vector by EcoRI digestion and transcribed and inoculated to plants as described above.

Viral genome characterization and sequence comparisons. Plasmid pBBSV-Co4 was subjected to double-stranded sequencing using primers positioned at an average of 400-bp intervals and the sequence assembled using the CAP3 program (16); the sequence is available in the GenBank database with accession no. EF153268. Major ORFs present within the sequence of BBSV-Co were detected using ORF Finder (28). Sequence alignments and inference of genetic distance were performed using Clustal W (29). In addition to the Chinese BBSV isolates BBSV-X (Xinjiang isolate; GenBank no. AY626780) and BBSV-N (Ningxia isolate; GenBank no. AF452884), the analyses within this study included the sequences of Olive latent virus-1 (OLV1; GenBank no. X85989), Tobacco necrosis virus D (TNV-D; GenBank no. D00942), Olive mild mosaic virus (OMMV; GenBank no. AY616760), TNV-A (GenBank no. AY546104), Leek white stripe virus (LWSV; GenBank no. X94560), Tomato bushy stunt virus (TBSV; GenBank no. M21958), and the satellite RNA of BBSV (GenBank no. NC_006460).

Primer extension analysis of the genome $5^{\prime}$ terminus. A fluorescein-conjugated DNA primer (BBSV-5FAM61-R; 5'CATACGGGATTGAATCCATGATCG3') antisense to the genomic RNA was designed to initiate reverse transcription at nucleotide 61 of BBSV-Co and used to generate a DNA sequence ladder from clone pBBSV-Co4 by cycle sequencing (ThermoSequencing kit; U.S. Biochemical Inc., Cleveland, $\mathrm{OH}$ ). The procedure outlined by Fekete et al. (12) was employed to produce run-off reverse transcripts which were separated in parallel with the DNA sequencing ladder on a $6 \%$ denaturing polyacrylamide gel (26). Fractionated products in the gel were detected on a Typhoon 9400 Variable Mode imaging system (GE Healthcare Inc.).

\section{RESULTS}

Extracts were prepared from sugar beet roots harvested near Greeley, CO in late 2006 with the intent of recovering BNYVV. Inoculation of $C$. quinoa cv. Tango resulted in the production of necrotic local lesions with chlorotic halos at 3 to 5 dpi (Fig. 2). Occasionally, the infection became systemic in the plant, inducing mosaic and vein clearing in upper leaves of infected plants (Fig. 

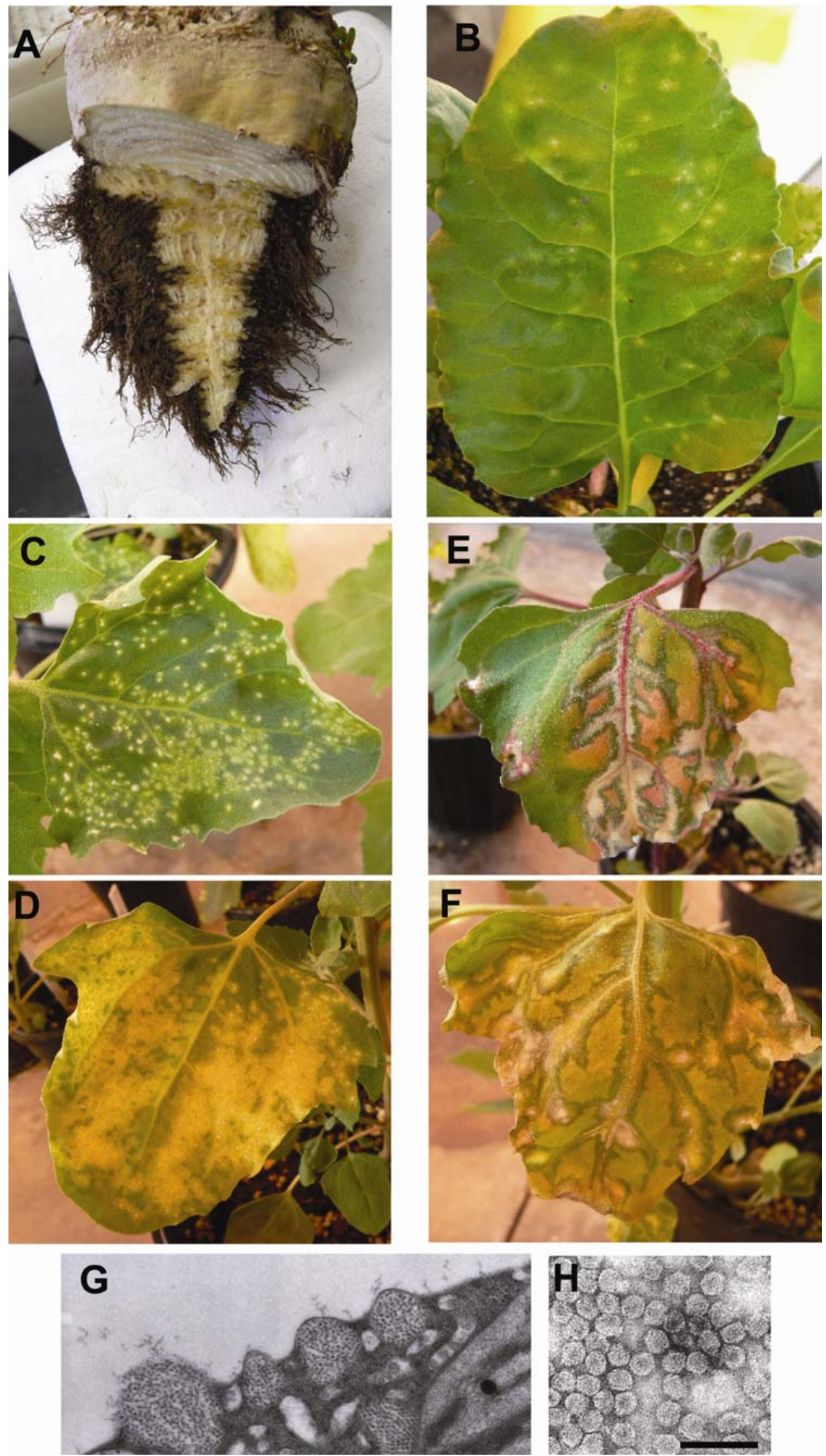

Fig. 2. Symptoms induced by novel virus and its particle morphology. A, Beet exhibiting severe Rhizomania symptoms and possessing a fibrous root was found to harbor the virus. Mechanical inoculation of plant foliage induced $\mathbf{B}$, diffuse chlorotic lesions on sugar beet and $\mathbf{C}$ and $\mathbf{D}$, necrotic or chlorotic local lesions on Chenopodium quinoa. $\mathbf{E}$ and $\mathbf{F}$, In $C$. quinoa, the virus occasionally produced systemic symptoms in which cleared veins were bordered by a dark green band. G, Examination of sectioned tissue by electron microscopy revealed dense aggregates of $\mathbf{H}$, spherical particles, which under higher magnification, appear icosahedral in shape $($ bar $=0.1 \mu \mathrm{m})$. 
$2 \mathrm{E}$ and $\mathrm{F}$ ). Transfer of the infection to leaves of sugar beet resulted in the induction of diffuse yellow lesions or pinpoint necrotic spots at $5 \mathrm{dpi}$, and no systemic movement was observed (Fig. 2).

The observation of fixed, embedded tissue obtained from symptomatic $C$. quinoa by transmission electron microscopy revealed aggregates of spherical particles within the cell cytoplasm (Fig. 2). Particle diameter after staining with uranyl acetate averaged $\approx 29 \mathrm{~nm}$. Virus particles were found in neither tissue of healthy, uninoculated plants, nor healthy tissue from inoculated plants (not shown).

An extraction scheme for small, spherical plant viruses was applied to the purification of the virus using different grinding buffers to optimize for eventual virus purification (17). Buffers containing sodium acetate, $\mathrm{pH} 5.2$; sodium citrate, $\mathrm{pH}$ 6.0; and sodium phosphate, $\mathrm{pH} 7.0$ were tested in crude extract preparation followed by PEG addition to precipitate virus. A comparison of proteins extracted from healthy and infected $C$. quinoa plants along with partially purified virus indicated (i) the presence of a probable $\mathrm{CP}$ of $M_{\mathrm{r}} \approx 25,000$ in infected extracts but not in healthy extracts and (ii) the reduction, relative to other extracts, of protein amount and complexity in the extract prepared with sodium acetate, $\mathrm{pH} 5.2$, with the exception of a single $M_{\mathrm{r}} \approx 25,000$ protein (Fig. 3). Examination of the partially purified preparation by electron microscopy revealed densely packed spherical particles of a size and morphology similar to particles observed in sections of infected C. quinoa (Fig. 2). Extraction of nucleic acid from the virion particles yielded a single RNase A-sensitive molecule (Fig. 3) which was directly infectious to inoculated $C$. quinoa and sugar beet (not shown), indicating the messenger-sense polarity of the genome.

In an effort to obtain rapid sequence information from a protein product of the novel virus, tryptic peptide fragments of the putative $\mathrm{CP}$ of the novel virus were subjected to mass spectroscopy, yielding partial amino acid sequence of the protein. Two peptides of sequence FGFTWY $\underline{R}$ and YATLAAITALTAND $\underline{R}$ ( $\underline{R}$ indicating the arginine residue recognized by trypsin) matched $100 \%$ with the amino acid sequence of regions within the CP of BBSV (Fig. 3). This information guided the development of DNA primers for the amplification of the novel virus by PCR. Assuming that the novel virus was a strain of BBSV and may have diverged in nucleotide sequence from the Chinese isolates, we searched for sequences conserved between BBSV-N and other necroviruses. An alignment between the 3,644-nt sequence of BBSV-N and that of TNV-D, the closest relative of BBSV within the genus Necrovirus, indicated a conserved sequence in the two genomes from nucleotides 2,187 through 2,214. A forward primer (BBSVmidfwd: 5'CTCCAGTTCTCTGGGGCATGAAAAC3') based on this sequence and a reverse primer based on the $3^{\prime}$ terminal $27 \mathrm{nts}$ of the BBSV-N genome (BBSVrev) (Fig. 1) were made and used to produce a 1.4-kbp DNA amplicon from the novel virus by PCR (not shown). Cloning and subsequent sequence analysis of the amplicon indicated that the region encoded a homolog of the BBSV-N CP. Nucleotide sequence conservation between the putative CP ORF of the unknown virus and that of BBSV-N was $90 \%$ and that of the encoded protein amino acid sequence was $97 \%$. Additionally, sequence conservation in the putative $3^{\prime}$ untranslated region ( $3^{\prime}$ UTR) was $96 \%$ based on this partial genome sequence. In addition to the sequence data, the virus produced localized, and occasionally systemic, infection on selected species of the family Chenopodiaceae and Tetragonia expansa. N. benthamiana supported symptomless, systemic infection. The results are in agreement with the host range for BBSV-N as reported by Cai et al. (6). Using the combined molecular and biological data, we designated the virus BBSV-Co as the Colorado isolate of BBSV and embarked on the cloning and characterization of the full-length genome.

Priority was placed on the construction of a genome-length cDNA clone from which infectious RNA could be transcribed prior to initiation of a genome sequencing effort. Accordingly, a clone designated pBBT7GAAG from which infectious, uncapped RNA was able to be transcribed was obtained from whole-genome RT-PCR. Symptoms induced by transcripts from pBBT7GAAG were similar to those produced by the same quantity of native virion RNA, but lesions expanded more slowly and were reduced in number. Combined with western blot analysis of infected tissue (Fig. 4), the data clearly indicated that replication of a cloned copy of the genome of BBSV-Co had occurred. Northern blot analysis of infected tissue using a denatured double-stranded DNA probe representing the $3^{\prime}$ terminal 300 bases of BBSV-Co sequence revealed the presence of an abundant viral genomic RNA accompanied by several RNAs of virus origin subgenomic in size (Fig. 4).

Application of 5'- and $3^{\prime}$-RACE to RNA prepared from BBSVCo indicated that the terminal 20 bases from both the $5^{\prime}$ and $3^{\prime}$ ends did not differ from that of the Chinese isolates of BBSV-N, with one exception: The published BBSV-N sequence has two 5' terminal adenosine nucleotides not present in the BBSV-Co clones recovered from 5'-RACE (not shown). Primer extension analysis was conducted and chimeric promoters yielding alternate start sites were made to address the discrepancy. Test constructs ranged from those possessing the 5 ' terminal sequence "GAAGAAAC....", where the bold text indicates the two adenosine nucleotides in question, to "GAAC...." where an internal adenosine nucleotide has been deleted (Fig. 1).

Primer extension analysis of virion RNA prepared from initial laboratory stocks of BBSV-Co indicated the absence of the 5' terminal AA nucleotides reported in the Chinese isolates (Fig. 5). Recovery of virion RNA derived from infections generated by inoculation with pBBT7GAAG also revealed a loss of the terminal AA nucleotides (Fig. 5). Furthermore, examination by primer extension indicated that virion RNA recovered from lesions induced by pBBT7A had reacquired the 5' end length encoded by clone pBBT7G (not shown). Finally, tests in which transcripts from pBBT7GAAG, pBBT7GAG, pBBT7GG, and pBBT7G were inoculated to $C$. quinoa revealed an increase in transcript-specific infectivity and virulence as $5^{\prime}$ nucleotides progressively were removed from the constructs. Transcripts from clone pBBT7A induced a precipitous ( $>20$-fold) reduction in the number of lesions on $C$. quinoa compared with the other constructs tested. Clone pBBT7G encoded a genome exhibiting the same 5' length and sequence in its untranslated leader as native BBSV-Co RNA and induced lesions similar in appearance and expansion rate to that induced by native BBSV-Co RNA; therefore, this clone henceforth was designated pBBSV-Co4.

The complete nucleotide sequence and genome organization of BBSV-Co4 was determined (Fig. 6) and compared with that of BBSV-N, -X, and other viruses. Linear alignment of the 3,642-nt genome of BBSV-Co with BBSV-N and BBSV-X using Clustal W (29) indicated a 93 and $92 \%$ similarity, respectively, between the genomes of these virus isolates, which is reflected in a distance dendrogram involving these sequences (Fig. 7). A BLAST (1) search with the BBSV-Co nucleotide sequence resulted in the recovery of the sequences of BBSV-X and BBSV-N with an $E$ value of 0.0 followed by that of TNV-D $\left(E\right.$ value of $\left.3 \mathrm{e}^{-13}\right)$. All other sequences were significantly less similar to the sequence of BBSV-Co. Neighbor-joining analysis within Clustal W of nucleotide sequence alignments between the polymerase and capsid protein genes of six necroviruses and Tomato bushy stunt virus (TBSV) as a distant relative confirmed that this virus is BBSV and supports its inclusion in the genus Necrovirus (Fig. 7). For the sake of brevity, comparison hereafter between BBSV-Co and the Chinese isolates of BBSV will refer only to the sequence of BBSV-N.

The major ORFs predicted from the sequence of Chinese BBSV sequence are conserved in BBSV-Co (Table 1); ORF designations of Yuan et al. (34) are used hereafter, except where 


\section{Chenopodium quinoa host}

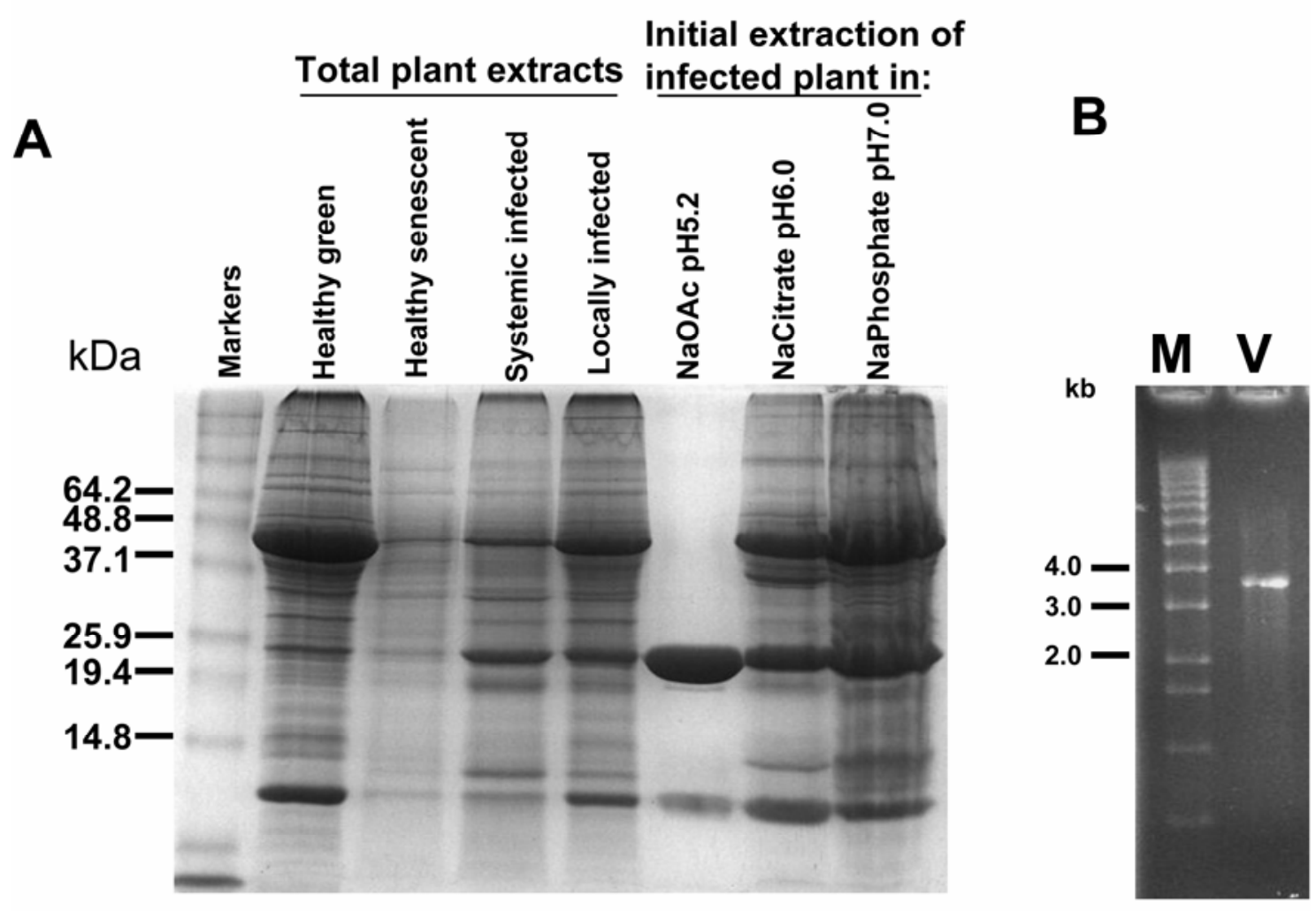

C

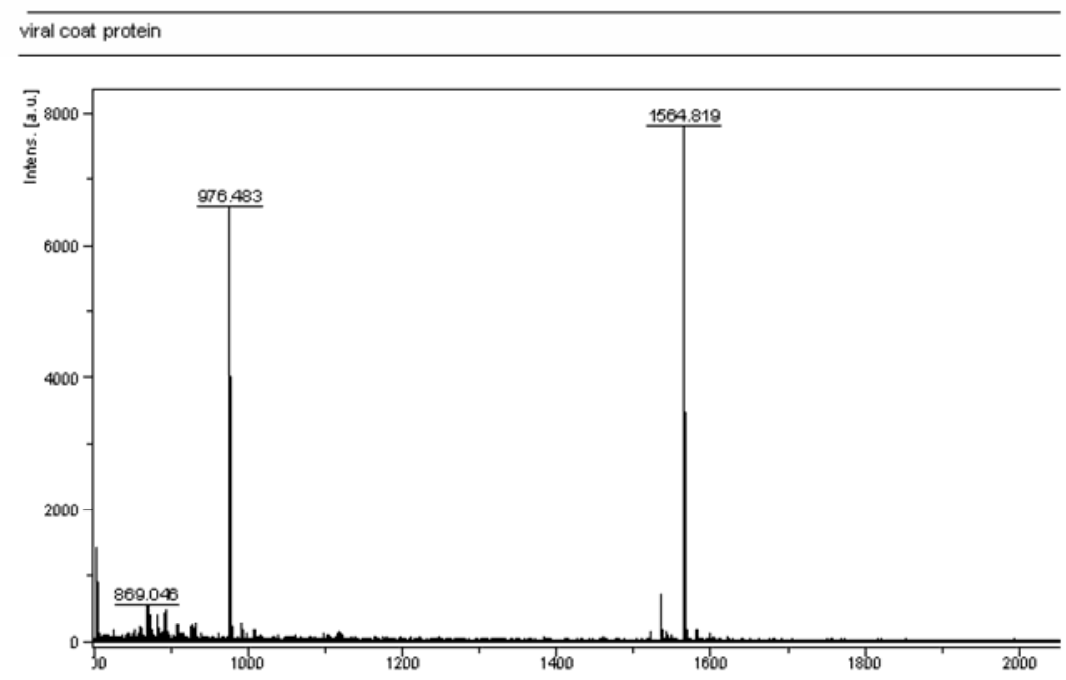

Fig. 3. Electrophoresis of $\mathbf{A}$, coat protein of novel virus in crude plant extracts and $\mathbf{B}$, virion RNA and $\mathbf{C}$, mass spectroscopy analysis of purified viral coat protein A, Crude protein extracts (lanes 2 to 5) or partially purified virus (lanes 6 to 8 ) were separated by $14 \%$ sodium dodecyl sulfate polyacrylamide gel electrophoresis. Extracts prepared from healthy green, healthy senescent, systemically infected, and locally infected tissues were compared with partially purified virus preparations in which the initial extraction buffer was composed of sodium acetate, $\mathrm{pH} 5.2$; sodium citrate, $\mathrm{pH} 6.0$; or sodium phosphate, $\mathrm{pH} 7.0$ buffers. Coelectrophoresis of protein size standards (lane $\mathrm{M}$ ) indicated that the single major coat protein of the virus migrated at $\approx 23 \mathrm{kDa}$. B, Electrophoresis of the singlestranded RNA extracted from partially purified virus (V) revealed a single molecule consistent in size with that predicted from the viral genome sequence (molecular weight standards, M). C, The amino acid sequence (lower panel in bold) of two tryptic peptides with masses of 976.5 and $1564.8 \mathrm{Da}$ (upper panel) derived from the virus coat protein matched those predicted for the coat protein from the Chinese isolate of BBSV. 
noted. The predicted p23 and the extension product p82 that results from suppression of the amber $\left(\mathrm{U}_{643} \mathrm{AG}\right)$ stop codon in BBSV-Co are 96 and 97\% similar, respectively, in amino acid sequence to their counterparts in BBSV-N. Although the predicted amino acid sequence of $\mathrm{p} 23$ encodes no distinctive motifs, that of the readthrough product encodes amino acid clusters conserved among RdRps, including the ... $\mathrm{G}_{529} \mathrm{DD}$... triad considered to be directly involved in polymer synthesis (5). The ORF encoding p4 in BBSV-Co is homologous to the ORF encoding $\mathrm{p} 5$ in BBSV-N, with $95 \%$ identity. A stop codon $\left(\mathrm{U}_{2120} \mathrm{AG}\right)$ in BBSV-Co prevents

A

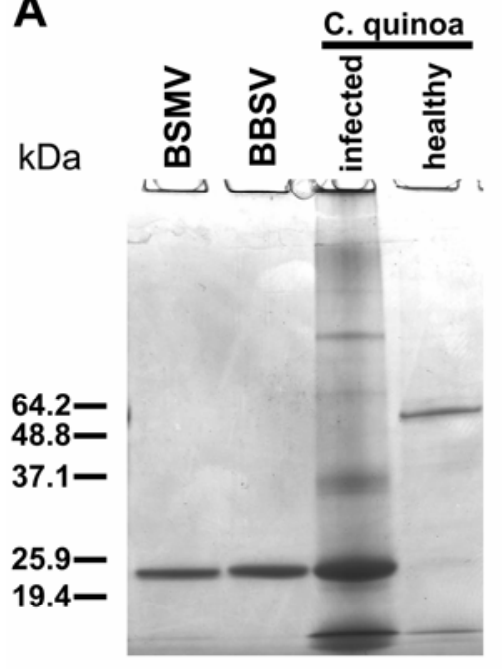

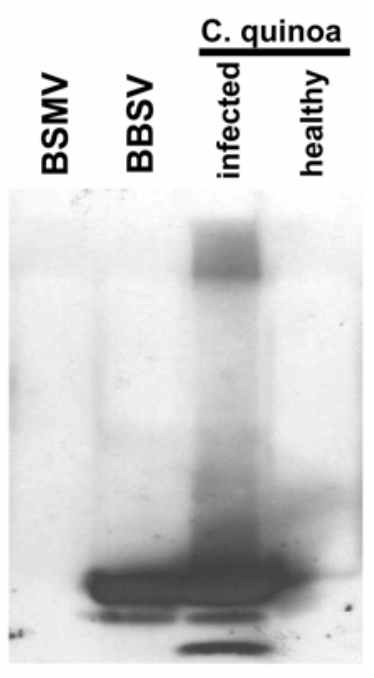

B

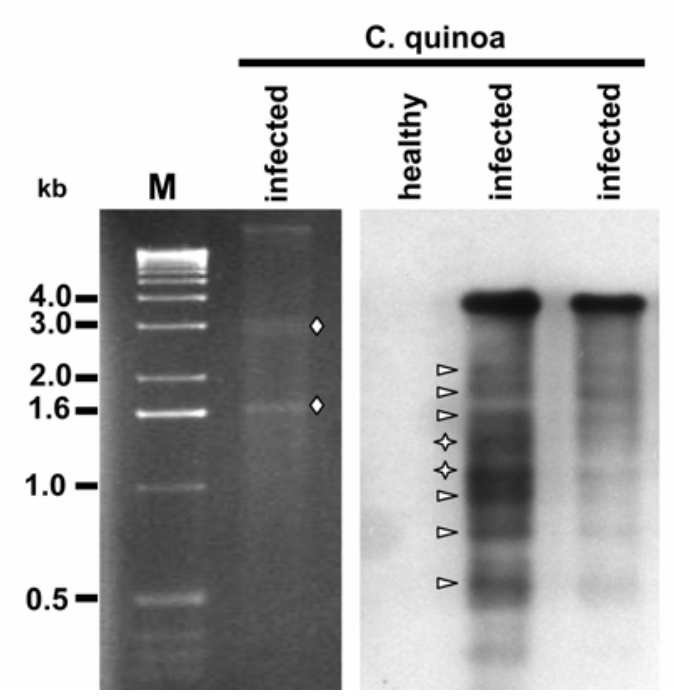

Fig. 4. Western and northern blot detection of Beet black scorch virus (BBSV$\mathrm{Co}$ ) in purified form and in infected plant extracts. A, Detection of virus coat protein employed rabbit antisera prepared against purified virus. A $12 \%$ sodium dodecyl sulfate polyacrylamide gel was used to separate proteins from infected (lane 3) or healthy (lane 4) Chenopodium quinoa leaf tissue. Included on the gel were purified BBSV (lane 2,1 $1 \mathrm{~g}$ ) and purified Barley stripe mosaic virus (BSMV) (lane 1). Coomassie blue staining of the gel (left panel) was compared with the western blot of a companion gel run in parallel (right panel). B, Synthetic transcript RNA was used to induce plant infections and total nucleic acids extracted from healthy and BBSV-Co-infected $C$. quinoa leaves were glyoxalated and separated on a $1 \%$ agarose gel. The left panel shows the gel stained with ethidium bromide, with the plant rRNAs indicated by open diamonds. In the right panel, a probe representing the $3^{\prime}$ terminal 300 nucleotides of the genome was produced using polymerase chain reaction and used to detect complementary sequences in a subset of lanes from the same gel. The 1-kb ladder (M) served as a reference ladder with, fragment lengths indicated in kilobase pairs $(\mathrm{kbp})$. Stars indicate potential sgRNAs of a size consistent with those detected during the replication of BBSV-N, whereas open arrows indicate potential additional sgRNAs. use of the $\mathrm{A}_{2105} \mathrm{UG}$ that initiates $\mathrm{p} 5$ in BBSV-N. Instead, a codon embedded within an excellent initiation context

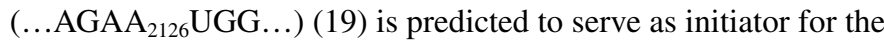
translation of this ORF. Production of $\mathrm{p} 7 \mathrm{a}, \mathrm{p} 7 \mathrm{~b}$, and $\mathrm{p} 5 \mathrm{~b}$ (designated $5^{\prime}$ by Yuan et al.) (34) in BBSV-Co are predicted to use the same respective initiation $\left(\mathrm{A}_{2226} \mathrm{UG}, \mathrm{A}_{2419} \mathrm{UG}\right.$, and $\mathrm{A}_{2432} \mathrm{UG}$ ) and termination $\left(\mathrm{U}_{2415} \mathrm{GA}, \mathrm{U}_{2614} \mathrm{GA}\right.$, and $\mathrm{U}_{2573} \mathrm{AA}$ ) codons as in BBSV-N. Encoded amino acid similarities in the predicted proteins between BBSV-Co and BBSV-N are $96 \%$ (p7a), 95\% (p7b), and 87\% (p5b).

The CP gene also is conserved in its position as $3^{\prime}$ terminal ORF of the genome and in its amino acid sequence. Although amino acid sequence similarity in the encoded cp is high (97\%) between BBSV-Co and BBSV-N, sequence conservation at the nucleotide level is the lowest (90\%) in ORF comparisons between the two viruses. It is proposed that the $\mathrm{CP}$ is translated from an sgRNA initiating at $\mathrm{G}^{2524}$ (Fig. 6) (34). Interestingly, an ORF, here designated p10 ( $\mathrm{A}_{2691} \mathrm{UG}$ to $\left.\mathrm{U}_{2973} \mathrm{GA}\right)$, is encoded out of frame, but within the $\mathrm{CP}$ ORF, and encodes a protein with a predicted mass of $9.9 \mathrm{kDa}$. The counterpart to this ORF in BBSV-N is interrupted by a single stop codon; suppression of this internal stop signal for the sake of comparison yields a predicted protein with $70 \%$ similarity between the two viruses. Similarity between BBSV-N and BBSV-Co in both the 5' (97\%) and 3' (96\%) UTRs is high relative to coding domains in the genome. The calculated $\mathrm{pI}$ of the $\mathrm{CP}$ based on the sequence of BBSV-Co is 9.6, whereas isoelectric focusing of the purified $\mathrm{CP}$ resulted in an experimental $\mathrm{pI}$ of 6.4. Analysis of the CP amino acid sequence with NetPhos 2.0 indicated four serine and six threonine residues as highly probable targets for phosphorylation. Application of mass spectroscopy to purified viral CP detected the presence of phosphorylated residues in this protein. Anti-BBSV antisera produced within the study was able to detect viral antigen with high sensitivity and specificity in double-antibody sandwich (DAS)-ELISA and western blots. The antiserum detected viral CP on a western blot of the virus and specifically detected the protein within a complex mixture of sugar beet proteins (Fig. 4).

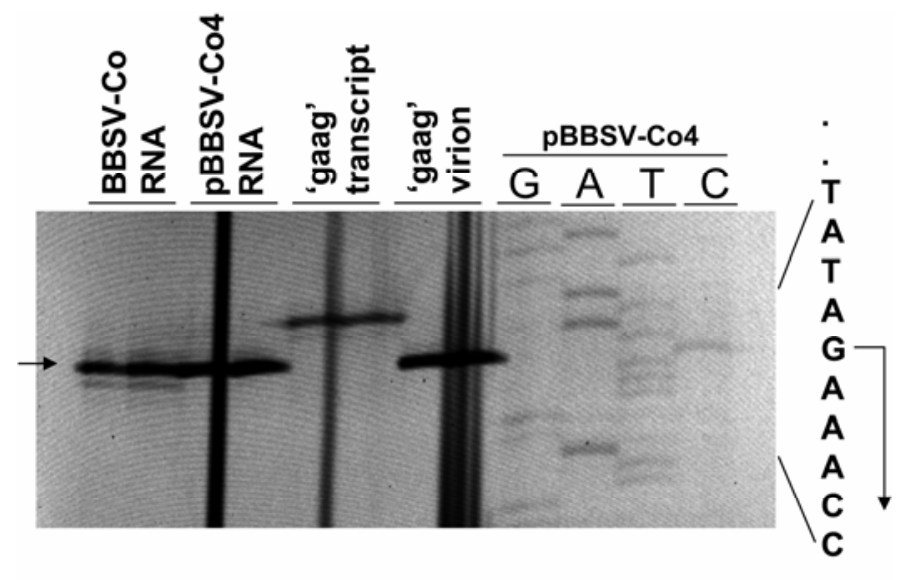

Fig. 5. Primer extension analysis of RNA prepared from crude virus preparations or synthesized from cloned template DNA. Run-off reverse transcripts primed with Beet black scorch virus (BBSV)-5FAM61-R (arrow) were produced from RNA extracted from native BBSV-Co virions (BBSV-Co RNA), RNA extracted from virions recovered after inoculation with transcript RNA of pBBSV-Co4 (pBBSV-Co4 RNA), pBBT7GAAG transcript RNA ('gaag' transcript), and RNA extracted from virions recovered from plants inoculated with pBBT7GAAG transcript RNA ('gaag' virion). A sequencing ladder generated with the same primer on template plasmid pBBSV-Co4 was co-electrophoresed on the gel and the sequence (indicated in +-strand orientation) of the TATA box of the T7 promoter and the start site of transcription is indicated at the right of the image. 


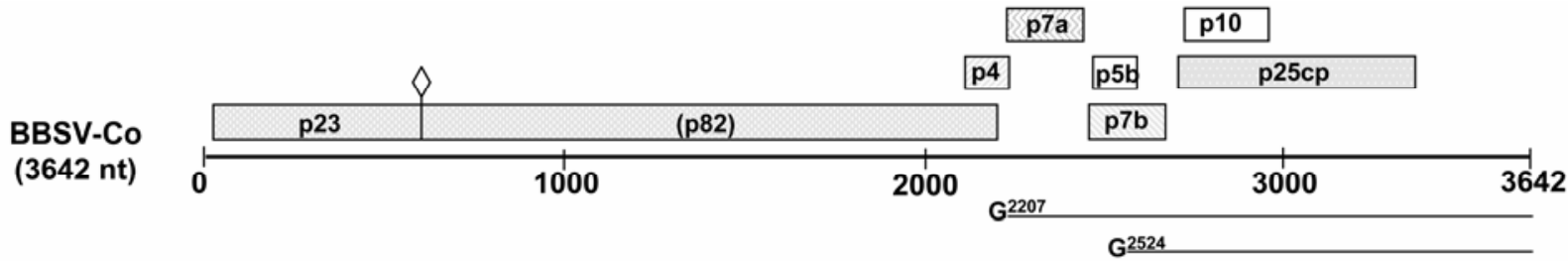

Fig. 6. Genome organization of Beet black scorch virus (BBSV-Co). Nomenclature is adopted from the necroviruses in general and from BBSV-N in particular. Refer to Table 1 for open reading frame (ORF) boundaries. The uncapped, single-stranded RNA genome is 3,642 nucleotides (nt) in length and codes for eight proteins with approximate mass indicated within each box. All ORFs predicted from the BBSV-Co sequence, except for the p10 ORF, also are represented in BBSV-N. Suppression of an amber (UAG; $\diamond$ ) stop codon terminating p23 synthesis gives rise to the RdRp protein p82. Subgenomic RNAs co-terminal with the $3^{\prime}$ end of the genome and predicted to initiate at $\mathrm{G}^{2207}$ and $\mathrm{G}^{2524}$ enable translation of all potential ORFs in the $3^{\prime}$ half of the genome except for p4. Genome numbering is in nucleotides.

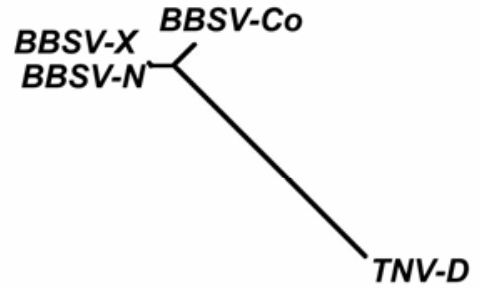

Whole genome
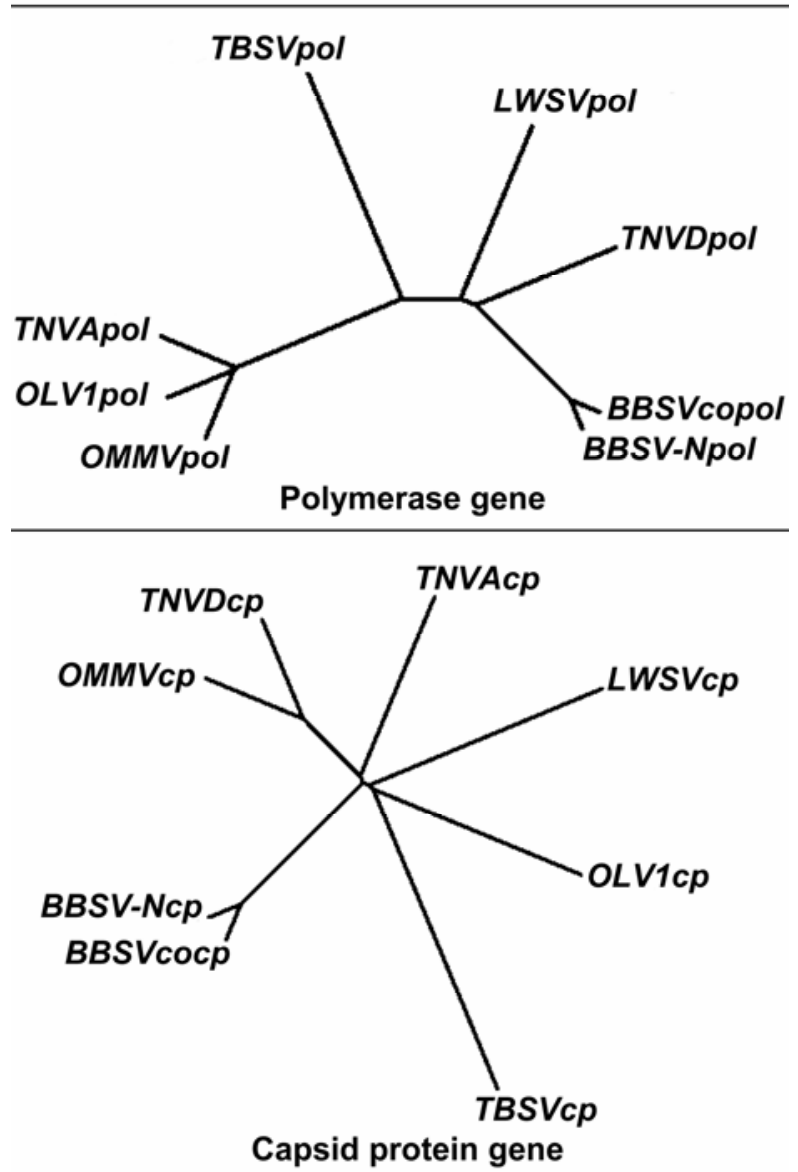

Fig. 7. Relative distance dendrograms using neighbor-joining for representative necroviruses and Tomato bushy stunt virus (TBSV) as an outgroup. Alignments between the nucleotide sequences of the whole genomes of Beet black scorch virus (BBSV-Co), BBSV-N, and BBSV-X (upper panel) and open reading frames encoding the polymerase (center panel) and capsid (lower panel) proteins reveal the close relationship between BBSV-N and BBSV-Co, as well as between these two viruses and Tobacco necrosis virus D (TNV-D). $\mathrm{LWSV}=$ Leek white stripe virus, $\mathrm{OLV}-1=$ Olive latent virus -1, and $\mathrm{OMMV}=$ Olive mild mosaic virus.

\section{DISCUSSION}

The principle soilborne viruses of sugar beet in the genera Benyvirus and Pomovirus all are known to have Polymyxa betae as their plasmodiophorid vector $(11,20)$. BBSV, by contrast, is reported to be transmitted by $O$. brassicae (18), consistent with the vectoring of other necroviruses by members of this genus (23). The present work constitutes the first characterization of a North American isolate of BBSV.

The genome of BBSV-Co is highly similar to that of the published sequence of BBSV-N from China, exhibiting 93\% sequence identity. The high sequence similarity is accompanied by conservation of the length and position of ORFs within the genome, as well as the predicted start sites for the production of two subgenomic RNAs $(7,34)$. Interestingly, the CP gene possesses the highest nucleotide substitution rate $(\approx 10 \%)$, yet maintains a 97\% identity in the encoded protein between the two genomes. The basis for this rate of apparent silent substitution is unknown. The high similarity in $5^{\prime}$ and $3^{\prime}$ UTRs between the U.S. and Chinese isolates, respectively, reflects the fact that these regions in related viruses have proven to be important for genome replication (33) and translation (27).

A single, major protein was identified in purified preparations of BBSV-Co. Minor protein constituents of lower molecular weight may represent host contaminants of the virus prep or natural or artifactual (breakdown of $\mathrm{CP}$, conformational variant of $\mathrm{CP}$, posttranslationally modified form of $\mathrm{CP}$, and so on) components of viral origin (Figs. 3 and 4). The low experimentally determined $\mathrm{pI}$ of the $\mathrm{CP}(\mathrm{pI}=6.4)$ was not predicted from the primary amino acid sequence $(\mathrm{pI}=9.6)$. Phosphate addition to serine, tyrosine, and threonine residues, however, would be expected to lower the $\mathrm{pI}$ of the protein (3) and the detected presence of phosphorylated residues in the $\mathrm{CP}$ is consistent with the experimental pI obtained. Phosphorylation in the CP constitutes a potential point for the regulation of this protein in the activities of RNA binding and encapsidation (2).

In an investigation by Yuan et al. (34) using infectious clones of BBSV-N, translation of the $\mathrm{CP}$ was confirmed to initiate at $\mathrm{A}^{2647} \mathrm{UG}$ and was shown to be dispensable for replication and localized movement of the virus in leaves of $C$. amaranticolor. The $\mathrm{CP}$ is putatively translated from an sgRNA (sgRNA2) initiating at nucleotide $\mathrm{G}^{2526}$. Although the elimination of translation of the four ORFs encoded by sgRNA1 (initiating at nucleotide $\mathrm{G}^{2209}$ ) was accompanied by a loss of local virus movement, it was proposed that this was due to the loss of functions encoded by proteins $\mathrm{p} 7 \mathrm{a}, \mathrm{p} 7 \mathrm{~b}$, and $\mathrm{p} 5$ ' (34). No known sgRNA would be capable of serving as mRNA for the production of the putative $\mathrm{p} 5$ protein of BBSV-N. Whereas elimination of potential start codons for the synthesis of p5 did not alter infectivity of the BBSV-N transcripts (34), a similar mutation in the TNV-D ${ }^{\mathrm{H}}$ homolog $\mathrm{p} 7_{1}$ did abolish whole plant infection by this virus, although replication in protoplasts was unaltered (21). Interestingly, the BBSVCo genomic sequence possesses a stop codon preventing the 
TABLE 1. Comparison of the genomes of Beet black scorch virus (BBSV)-Co and BBSV-N

\begin{tabular}{|c|c|c|c|c|}
\hline ORF or element ${ }^{a}$ & BBSV-Co ${ }^{b}$ & BBSV-N & $\%$ Similarity $(\mathrm{nt})^{\mathrm{c}}$ & $\%$ Similarity $(a a)^{\mathrm{d}}$ \\
\hline Complete genome & 3,642 & 3644 & $3,387 / 3642(92)$ & \\
\hline $5^{\prime}$ UTR & $1-33$ & $1-35$ & $32 / 33(97)$ & \\
\hline p23 & $34-645$ & $36-647$ & $564 / 612(92)$ & $195 / 203(96 \%)$ \\
\hline p4 & $2,126-2,242$ & $2,107-2,244$ & 129/138 (93) & $32 / 38(84 \%)$ \\
\hline p7a & $2,226-2,417$ & $2,228-2,419$ & 183/192 (95) & $61 / 63(96 \%)$ \\
\hline p7b & $2,419-2,616$ & $2,421-2,618$ & 189/198 (95) & $62 / 65(95 \%)$ \\
\hline p5b & $2,432-2,575$ & $2,434-2,577$ & $137 / 144(95)$ & $41 / 47(87 \%)$ \\
\hline $3^{\prime}$ UTR & $3,344-3,642$ & $3,346-3,644$ & $290 / 299(96 \%)$ & \\
\hline
\end{tabular}

${ }^{a}$ Genetic elements for comparison include dispersed open reading frames (ORFs) and untranslated regions (UTRs) located near the termini of the genome. The $p 4$ gene of BBSV-Co is homologous and compared with $p 5$ from BBSV-N.

${ }^{b}$ ORF numbering includes the first nucleotide of the start codon and the last nucleotide of the termination codon.

' For the comparison of the 5' UTR, the first 2 nt of the BBSV-N sequence were omitted.

${ }^{\mathrm{d}}$ In comparing the $\mathrm{p} 82$ proteins, the stop specified by the internal U643AG codon of BBSV-Co, and the corresponding position for BBSV-N, was replaced by Tyrosine (Tyr). For the comparison of the predicted p5 protein, the BBSV-N protein was truncated from the amino terminus to A2128UG.

e Not determined.

production of $\mathrm{p} 5$, but use of an alternate $\mathrm{A}^{2126} \mathrm{UG}$ would permit production of an $\approx 4-\mathrm{kDa}$ protein with high similarity to the homologous gene in BBSV-N (Table 1; Fig. 6). In addition, an ORF potentially directing synthesis of a $10-\mathrm{kDa}$ protein is embedded out of frame within the CP ORF of BBSV-Co, but not in that of the Chinese isolates; the possibility that this ORF is indeed expressed remains to be determined.

Analysis of BBSV-Co genome-related RNAs indicates the potential for the production of sgRNAs homologous to sgRNA1 and sgRNA2 of BBSV-N. Additional potential sgRNAs were detected in northern blots of $C$. quinoa tissue infected with BBSV-Co (Fig. 4); however, whether these represent biologically relevant sgRNAs, defective-interfering or satellite RNAs (33), or are simply breakdown products of the genomic RNA remains to be determined. Although a satellite RNA has been characterized that is associated with BBSV-X (15), its presence would not be anticipated in infections initiated by synthetic transcripts of the BBSV-Co genome.

The RdRp encoded within the BBSV genome harbors the sole catalytic motif detected in computer analysis of the ORFs. The $\mathrm{G}_{529} \mathrm{DD}$ amino acid triad, conserved in RNA polymerizing enzymes (5) and located near the $\mathrm{C}$ terminus of the encoded readthrough p82 protein, is a hallmark of RdRps. Potential signal peptide and transmembrane domains encoded within the first 45 $\mathrm{N}$-terminal amino acids also are located on this and, by default, the $\mathrm{p} 23$ protein (predicted by InterProScan). These domains may serve the homologous function of the targeting of replication complexes to intracellular membranes $(22,33)$. Based on the neighbor-joining method to determine genetic distance between representative necroviruses, the classification of the virus described here as BBSV is clearly seen (Fig. 7). Moreover, the role of recombination in the evolution of the necroviruses (33) is illustrated by the relative close similarity between TNV-D and OMMV based on their CP genes, but between OMMV and TNVA based on their RdRp genes.

Using site-directed mutants of BBSV-Co and primer extension from transcript RNA, transcript-derived virion RNA, and native virion RNA, it was demonstrated that BBSV-Co possesses the terminal sequence 5'GAAACCTAACC....3' compared with the sequence 5'AAGAAACCTAACC.....3' proposed for BBSV-N and BBSV-X. This is supported by several observations. First, virion RNA derived from infections induced by transcripts bearing the additional adenosine nucleotides was found to lack these bases, suggesting loss of these nucleotides during genome replication. Second, analysis of replicated virus derived from transcripts that possessed the $5^{\prime}$ end sequence 5'GAACCTAACC......3' (missing an internal adenosine nucleotide) and that induced a limited number of infection foci indicated that a sequence of a length corresponding to 5'GAAACCTAACC...3' had been regenerated, possibly by addition of a nontemplated nucleotide during replication (14). Third, optimal transcript infectivity resulted when the $5^{\prime}$ end sequence was 5'GAAACCTAACC...3' with no additional $5^{\prime}$ terminal bases. Finally, a comparison of the $5^{\prime}$ end sequence of BBSV-Co with that of the closely related necroviruses LWSV and TNV-D and that of the satellite RNA of BBSV indicates a lack of these two nucleotides (Fig. 1). Combined, the data suggest that the BBSV $5^{\prime}$ terminal sequence is $5^{\prime} \mathrm{GA}$ AACCTAACC..... $3^{\prime}$.

BBSV derives its name from black scorch symptoms on leaves of sugar beet plants ostensibly due to viral infection. The sugar beet plants obtained as the source of BBSV-Co did not exhibit these symptoms and were indistinguishable in phenotype from sugar beet exhibiting Rhizomania. It is possible that the difference in pathotype is grounded in nucleotide differences between BBSV-Co and the Chinese isolates of BBSV. The availability of infectious cDNA clones and antisera for both isolates of the virus now provides the basis for investigating this question and the potential involvement of BBSV in intensifying Rhizomania disease.

\section{ACKNOWLEDGMENTS}

Mention of a trademark or proprietary product does not constitute a guarantee or warranty of the product by the USDA or imply approval to the exclusion of other products that may also be suitable. This work was supported by USDA-ARS CRIS 5442-22000-033-00D (J. J. Weiland, project leader). We thank J. Neubauer, G. Nielsen, J. Prenni, R. McClean, S. Payne, and A. McGarvey for excellent technical assistance.

\section{LITERATURE CITED}

1. Altschul, S. F., Gish, W., Miller, W., Myers, E. W., and Lipman, D. J. 1990. Basic local alignment search tool. J. Mol. Biol. 215:403-410.

2. Atabekov, J. G., Rodionova, N. P., Karpova, O. V., Kozlovsky, S. V., Novikov, V. K., and Arkhipenko, M. V. 2001. Translational activation of encapsidated Potato virus $X$ RNA by coat protein phosphorylation. Virology 286:466-474.

3. Bjellqvist, B., Hughes, G. J., Pasquali, C., Paquet, N., Ravier, F., Sanchez, J.-C., Frutiger, S., and Hochstrasser, D. F. 1993. The focusing positions of polypeptides in immobilized $\mathrm{pH}$ gradients can be predicted from their amino acid sequences. Electrophoresis 14:1023-1031.

4. Blom, N., Gammeltoft, S., and Brunak, S. 1999. Sequence- and structurebased prediction of eukaryotic protein phosphorylation sites. J. Mol. Biol. 294:1351-1362.

5. Bruenn, J. A. 2003. A structural and primary sequence comparison of the viral RNA-dependent RNA polymerases. Nucleic Acids Res. 31:1821-1829.

6. Cai, Z. N., Chen, D. H., Wu, M. S., Cui, X. M., Yu, J. L., and Liu, Y. 1993. Identification of pathogenic virus of beet black scorch disease and detection by synthesized cDNA probes. J. Beijing Agric. Univ. 19:112. 
7. Cao, Y. H., Cai, Z. N., Ding, Q., Li, D. W., Han, C. G., Yu, J. L., and Liu, Y. 2002. The complete nucleotide sequence of Beet black scorch virus (BBSV), a new member of the genus Necrovirus. Arch. Virol. 147:24312435.

8. Clark, M. F., and Adams, A. N. 1977. Characteristics of the microplate method of enzyme-linked immunosorbent assay for the detection of plant viruses. J. Gen. Virol. 34, 475-483.

9. Cui, X. M. 1988. An icosahedral virus found in sugar beet. J. Xinjiang Shihezi Agric. Coll. 10:73-78.

10. Cui, X. M., Cai, Z. N., Wu, J., and Liu, Y. 1991. Study on symptom pattern of sugarbeet rhizomania disease. Plant Prot. 17:5-7.

11. Duffus, J. E., and Ruppel, E. G. 1993. Diseases. Pages 346-427 in: The Sugarbeet Crop. D. A. Cooke and R. K. Scott, eds. Chapman and Hall, London.

12. Fekete, R. A., Miller, M. J., and Chattoraj, D. K. 2003. Fluorescently labeled oligonucleotide extension: a rapid and quantitative protocol for primer extension. BioTechniques 35:90-94.

13. Gibbs, A. and Harrison, B. 1976. Plant Virology: The Principles. Edward Arnold (Publ.), London

14. Guan, H., and Simon, A. E. 2000. Polymerization of non-template bases prior to transcription initiation at the $3^{\prime}$ ends of templates by an RNAdependent RNA polymerase: An activity involved in $3^{\prime}$-end repair of viral RNAs. Proc. Natl. Acad. Sci. USA 97:12451-12456

15. Guo, L. H., Cao, Y. H., Li, D. W., Niu, S. N., Cai, Z. N., Han, C. G., Zhai, Y. F., and Yu, J. L. 2005. Analysis of nucleotide sequences and multimeric forms of a novel satellite RNA associated with Beet black scorch virus. J. Virol. 79:3664-3674.

16. Huang, X, and Madan, A. 1999. CAP3: A DNA sequence assembly program. Genome Res. 9:868-877.

17. Hull, R. 1992. Viruses. In: Molecular Plant Pathology: A Practical Approach. IRL Press, Oxford.

18. Jiang, J. X., Zhang, J. F., Che, S. C., Yang, D. J., Yu, J. L., Cai, Z. N., and Liu, Y. 1999. Transmission of beet black scorch virus by Olpidium brassicae. J. Jiangxi Agric. Univ. 21:525-528.

19. Joshi, C. P., Zhou, H., Huang, X., and Chiang, V. L. 1997. Context sequences of translation initiation codon in plants. Plant Mol. Biol. 35:993-1001.

20. Lennefors, B.-L., Savenkov, E. I., Mukasa, S. B., and Valkonen, J. P. T. 2005. Sequence divergence of four soilborne sugarbeet-infecting viruses. Virus Genes 31:57-64.

21. Molnar, A., Halvelda, Z., Dalmay, T., Szutorisz, H., and Burgyan, J. 1997. Complete nucleotide sequence of tobacco necrosis strain $\mathrm{D}^{\mathrm{H}}$ and genes required for RNA replication and virus movement. J. Gen. Virol. 78:12351239.

22. Panavas, T., Hawkins, C. M., Panaviene, Z., and Nagy, P. D. 2005. The role of the p33:p33/p92 interaction domain in RNA replication and intracellular localization of p33 and p92 proteins of Cucumber necrosis tombusvirus. Virology 338:81-95.

23. Rochon, D., Kakani, K., Robbins, M., and Reade, R. 2004. Molecular aspects of plant virus transmission by Olpidium and plasmodiophorid vectors. Annu. Rev. Phytopathol. 42:211-241.

24. Rush, C. M., Liu, H.-Y., and Lewellen, R. T. 2006. The continuing saga of Rhizomania of sugar beets in the United States. Plant Dis. 90:4-15.

25. Russo, M., Burgyan, J., and Martelli, G. P. 1994. Molecular biology of the tombusviridae. Adv. Virus Res. 44:381-428.

26. Sambrook, J. and Russell, D. 2001. Molecular Cloning: A Laboratory Manual, 3rd ed. Cold Spring Harbor Laboratory, Cold Spring Harbor, NY.

27. Shen, R., and Miller, W. A. 2006. Structures required for poly(A) tailindependent translation overlap with, but are distinct from, capindependent translation and RNA replication signals at the $3^{\prime}$ end of tobacco necrosis virus RNA. Virology doi:10.1016/j.virol.2008.08.054.

28. Stothard, P. 2000. The Sequence Manipulation Suite: JavaScript programs for analyzing and formatting protein and DNA sequences. Biotechniques 28:1102-1104

29. Thompson, J. D., Higgins, D. G., and Gibson, T. J. 1994. CLUSTAL W: Improving the sensitivity of progressive multiple sequence alignment through sequence weighting, position-specific gap penalties and weight matrix choice. Nucleic Acids Res. 22:4673-4680.

30. Weiland, J. J., and Dreher, T. W. 1989. Infectious TYMV RNA from cloned cDNA: Effects in vitro and in vivo of point substitutions in the initiation codons of two extensively overlapping ORFs. Nucleic Acids Res. 17:4675-4687.

31. Weiland, J. J., and Edwards, M. C. 1994. Evidence that the aa gene of barley stripe mosaic virus encodes determinants of pathogenicity to oat. Virology 201:116-126.

32. Weiland, J. J., Larson, R. L., Freeman, T. P., and Edwards, M. C. 2006. First Report of Beet black scorch virus in the United States. Plant Dis. 90:828.

33. White, K. A., and Nagy, P. D. 2004. Advances in the molecular biology of tombusviruses: gene expression, genome replication, and recombination. Prog. Nucleic Acid Res. Mol. Biol. 78:187-226.

34. Yuan, X., Cao, Y., Xi, D., Guo, L., Han, C., Li, D., Zhai, Y., and Yu, J. 2006. Analysis of the subgenomic RNAs and the small open reading frames of Beet black scorch virus. J. Gen. Virol. 87:3077-3086. 